\title{
Ratio of S-adenosylmethionine to S-adenosylhomocysteine as a sensitive indicator of atherosclerosis
}

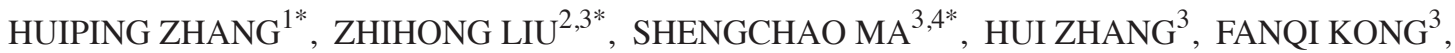 \\ YANGYANG HE ${ }^{3}$, XIAOLING YANG ${ }^{3}$, YANHUA WANG ${ }^{3}$, HUA XU $^{3}$, ANNING YANG $^{3}$, JUE TIAN $^{3}$, \\ MINGHAO $\mathrm{ZHANG}^{3}, \mathrm{JUN} \mathrm{CAO}^{3}$, YIDENG JIANG ${ }^{5}$ and XIONG GUO ${ }^{2}$ \\ ${ }^{1}$ Department of Prenatal Diagnosis Center, General Hospital of Ningxia Medical University, Yinchuan, Ningxia 750004; \\ ${ }^{2}$ Department of Public Health, Xi'an Jiaotong University College of Medicine, Xi'an, Shaanxi 710061; \\ ${ }^{3}$ Key Laboratory of Cardiovascular and Cerebrovascular Diseases, Ningxia Medical University, Yinchuan, Ningxia 750004; \\ ${ }^{4}$ Department of Physiology, West China School of Preclinical and Forensic Medicine, Sichuan University, Chengdu, \\ Sichuan 610041; ${ }^{5}$ Department of Pathophysiology, Basic Medical School, Ningxia Medical University, \\ Yinchuan, Ningxia 750004, P.R. China
}

Received April 18,2015; Accepted March 9, 2016

DOI: $10.3892 / \mathrm{mmr} .2016 .5230$

\begin{abstract}
The present study aimed to confirm whether the ratio of S-adenosylmethionine (SAM) to S-adenosylhomocysteine (SAH) is a sensitive indicator, and whether it can be used as a biomarker for the clinical diagnosis of atherosclerosis. Apolipoprotein E (ApoE) ${ }^{-/}$mice were randomly divided into four groups and fed with a high methionine diet for 15 weeks. Serum levels of homocysteine (Hcy) were measured using an automatic biochemistry analyzer. The concentrations of SAM and SAH were determined using high-performance liquid chromatography. The methylation levels of B1 repetitive elements, adipocyte fatty acid binding protein (FABP4), monocyte chemoattractant protein-1 (MCP-1) and extracellular superoxide dismutase (EC-SOD) were analyzed using nested touchdown-methylation-specific-polymerase chain reaction analysis. After 15 weeks, compared with the normal control group, serum concentrations of Hcy were significantly increased by 1.15-, 2.54- and 1.17-fold $(\mathrm{P}<0.05)$ in the $\mathrm{ApoE}^{-1-}$ control group, Meth group and Meth-F group, respectively. The sizes of the atherosclerotic lesions were increased in the
\end{abstract}

Correspondence to: Professor Xiong Guo, Department of Public Health, Xi'an Jiaotong University College of Medicine, 76 West Yanta Road, Xi'an, Shaanxi 710061, P.R. China

E-mail: jydcan@126.com

Professor Yideng Jiang, Department of Pathophysiology, Basic Medical School, Ningxia Medical University, 1160 Shengli Street, Yinchuan, Ningxia 750004, P.R. China

E-mail: solarmsc@163.com

*Contributed equally

Key words: S-adenosylmethionine/S-adenosylhomocysteine ratio, DNA methylation, atherosclerosis, homocysteine
$\mathrm{ApoE}^{-/-}$control group, Meth group and Meth-F group, by up to 1.44-, 2.40- and 1.45-fold, respectively, compared with the normal control group $(\mathrm{P}<0.05)$. The concentrations of SAM were significantly increased by 3.02-, 3.42- and 2.46-fold in the $\mathrm{ApoE}^{-/}$control group, Meth group and Meth-F group, respectively $(\mathrm{P}<0.05)$. The ratios of SAM/SAH were increased by 1.67- and 2.75-fold in the in $\mathrm{ApoE}^{-/-}$control group and Meth group, respectively, compared with the normal control group. The methylation levels of B1 repetitive elements, FABP4, MCP-1 and EC-SOD were decreased and exhibited hypomethylation. The methylation statuses of these genes were correlated with the ratio of the serum levels of SAM and SAH. These findings suggested that the SAM/SAH ratio is a biomarker and may provide a sensitive indicator for the clinical diagnosis of atherosclerosis.

\section{Introduction}

Atherosclerosis (AS) is a leading contributor to mortality rates in developed countries; it is a complex and multifactorial disease and is affected by genetic and environment factors (1). Due to the methods of diagnosing AS being limited and the poor reversibility of the disease, accurate and timely detection of atherosclerotic lesions is particularly important. Several techniques have been used for the analysis of AS clinically, including X-ray angiography, computed tomography, magnetic resonance imaging and intravascular ultrasound. However, the majority of these methods are unable to detect AS until the onset of symptoms of AS (2), and several of the biological changes occur in one event with no prior symptoms. Therefore, the identification of an suitable method of imaging AS prior to an advanced stage is likely to be of significance for the prevention and treatment of AS.

Several retrospective and prospective studies in humans and animals have shown that hyperhomocysteinemia (HHcy) is an independent risk factor for AS, which contributes to atherosclerotic plaque formation and development (3), and the 
toxicity in AS is associated with the metabolism of homocysteine (Hcy). Hcy functions as an intermediate in methionine metabolism and is converted to methionine, the precursor of $\mathrm{S}$-adenosylmethionine (SAM), which is the primary methyl group donor in the majority of biological methylation events, particularly DNA. Following transfer of the methyl group, SAM is converted to S-adenosylhomocysteine (SAH), a potent inhibitor of several SAM-dependent methyltransferases (4). Previous investigations have suggested that DNA methylation may cause disease either by silencing genes through hypermethylation or activating genes through hypomethylation under HHcy $(5,6)$. Aberrant DNA methylation serves as an important mechanism, which controls gene expression in a variety of chronic diseases, particularly AS (7). In addition, associated studies have confirmed the clinical value of certain DNA methylation markers for the early detection of cancer, risk assessment and prediction of therapeutic responses, as altered DNA methylation occurs prior to the onset of symptoms of diseases, including AS (8). Kerins et al (9) found that SAH was a more sensitive indicator of risk in a group of patients with a diagnosis of cardiovascular disease, compared with Hcy, however, other evidence has suggested that the appearance of SAH in the plasma following an oral load of SAM and following an oral load of methionine $(10,11)$. In addition, patients with end-stage renal disease had higher plasma levels of SAM and SAH, as well as Hcy (12). As there are differences among findings, the identification of novel and more sensitive biomarkers for imaging AS prior to the appearance of symptoms is important.

Increasing attention has focussed on the mechanisms of AS, and several hypotheses have been accepted, including oxidative stress, inflammation and altered methylation levels of certain typical AS-associated genes (13), including extracellular superoxide dismutase (EC-SOD), adipocyte fatty acid binding protein (FABP4) and monocyte chemoattractant protein-1 (MCP-1) (14-16), which are involved in the mechanisms of HHcy-induced AS. There have been several attempts to elucidate the mechanisms of AS and DNA methylation. Lakshmi et al (17) found that alterations in the methylation level of EC-SOD contributed to increased oxidative stress and increased the susceptibility of cardiovascular disease, particularly AS. Liu et al (18) found that MCP-1 is a potent chemokine and important in AS, in addition to reporting that the hypomethylation of $\mathrm{CpG}$ sites in the MCP-1 promoter region may be important in the vascular complications of type 2 diabetes. In our previous studies, it was demonstrated that $\mathrm{B} 1$ repetitive element hypomethylation is involved in the pathogenesis of AS (19), in which EC-SOD, FABP4, MCP-1 and $\mathrm{B} 1$ repetitive elements were analyzed to determine their DNA methylation levels to confirm the association between the methylation status of these genes and the development of AS.

The present study was designed to examine the correlation between the methylation levels of typical AS-associated genes and the ratio of SAM/SAH in atherosclerotic-based apolipoprotein $\mathrm{E}(\mathrm{ApoE})^{-/-}$mice, and to determine whether the $\mathrm{SAM} / \mathrm{SAH}$ ratio is a superior biomarker for AS. In addition, the present study aimed to investigate whether the SAM/SAH ratio may be used as a rational factor in diagnosing $\mathrm{AS}$ in the future.

\section{Materials and methods}

Animals and diets. A total of 48 male ApoE ${ }^{-/-}$mice (6 weeks old; $18-22 \mathrm{~g}$ in weight) were provided by the Animal Center of Peking University (Beijing, China) and were bred in the Animal Center of Beijing University (Beijing China). The mice were housed (6 mice per cage) in a climate-controlled room $\left(22 \pm 2^{\circ} \mathrm{C}\right)$ with a $12 \mathrm{~h}$ light/dark cycle, and provided with free access to water and a pelleted diet (Keaoxieli, Beijing, China) for 15 weeks. The animals were divided into the following groups: Normal control group $(n=12)$, wild-type mice with a regular mouse diet; ApoE $E^{-/-}$control group $(n=12)$, $\mathrm{ApoE}^{-/-}$mice with a regular mouse diet; high-methionine group (Meth group; $\mathrm{n}=12$ ), ApoE $\mathrm{E}^{-/}$mice with a regular mouse diet $+1.7 \%$ methionine; high-methionine+folic acid and vitamin $\mathrm{B}_{12}$ group (Meth-F group; $\mathrm{n}=12$ ), $\mathrm{ApoE}^{-/-}$mice with a regular mouse diet $+1.7 \%$ methionine $+0.006 \%$ folic acid $+0.0004 \%$ vitamin $\mathrm{B}_{12}$. The experimental procedures used on the mice were approved by the Ningxia Medical University Animal Care and Use Committee and were conducted according to the Ningxia Medical University Animal Care Committee guidelines.

Determination of serum levels of Hcy, SAM and SAH. After 15-week experimental diets, mice were euthanized by abdominal injection with $20 \%$ ethylcarbamate $(5 \mathrm{ml} / \mathrm{kg})$, and blood was immediately collected $(\sim 0.8-1.2 \mathrm{ml})$ to measure serum Hcy, SAM, SAH levels. Blood was collected by cardiac puncture and serum was separated by centrifugation $\left(1,000 \mathrm{x} \mathrm{g}\right.$ for $10 \mathrm{~min}$ at $\left.4^{\circ} \mathrm{C}\right)$. The concentrations of Hcy were measured using an ADVIA 2400 Chemistry System (Siemens AG, Munich, Germany). Serum concentrations of SAM and SAH were measured using high-performance liquid chromatography (HPLC). The supernatant of each sample was filtered through a $0.22 \mu \mathrm{m}$ filter (EMD Millipore, Billerica, MA, USA) and was then loaded into a C18 column (250x4.6 mm ID; $5 \mu \mathrm{m}$ particles; Shimadzu Corporation, Kyoto, Japan), run by a water HPLC system (D-2000 Elite HPLC system; Hitachi High-Technologies Corporation, Tokyo, Japan) and connected to an ultraviolet detector. The absorption values of the eluted compounds were monitored at $(\lambda)$ ex $=254 \mathrm{~nm}$. Chromatograms were recorded using an HPLC integrator, and quantification was performed by automatic peak area integration. SAM and SAH standards were used to identify the elution peaks. All analyses were performed in triplicate.

Tissue preparation and evaluation of atherosclerotic lesions in the aorta. The aorta were excised and placed in plastic processing cassettes to avoid warping of tissues. The aortas were embedded in glycolmethacrylate (Technovit 7100; Kulzer, Wehrheim, Germany). To quantify plaques by stereological methods, $\sim 10$ evenly spaced sections of each aortic segment were sampled. The blocks were exhaustively sectioned at $10 \mu \mathrm{M}$ and stained with hematoxylin and eosin (H\&E; Boster Biological Technology, Ltd., Wuhan, China) $(19,20)$ as follows: The aortas were separated carefully and then put into $4 \%(\mathrm{w} / \mathrm{v})$ formalin for $24 \mathrm{~h}$. The samples subsequently underwent washing with water, dehydration with a Citadel tissue processor (Thermo Fisher Scientific, Inc.), clearing of surplus liquid from tissues, embedding using a Histostar tissue embed- 
ding system (Thermo Fisher Scientific, Inc.), coating with paraffin wax, slicing (thickness, $4 \mu \mathrm{M}$ ) on a HM340E microtome (Thermo Fisher Scientific, Inc.) and H\&E staining. The sampled sections of the aorta were projected onto a table top at 40x magnification using a BX50F4 microscope (Olympus Corporation, Tokyo, Japan). An orthogonal grid $(2 \times 2 \mathrm{~cm})$ was superimposed over the projected image, and the number of grid points overlying the intima and media of the aorta were counted for relative atherosclerotic plaque areas (21).

Nested touchdown-methylation specific polymerase chain reaction ( $n t-M S P)$ analysis. Blood used for separation of mononuclear cells was fresh and free of clots, in preservative-free anticoagulant. Histopaque 1083 (Sigma-Aldrich, St. Louis, MO, USA) was added to centrifuge tubes, then whole blood was carefully layered onto the Histopaque 1083 surface and centrifuged at $400 \mathrm{x} \mathrm{g}$ for $30 \mathrm{~min}$ at room temperature. After centrifugation, the upper layer was aspirated carefully with a plastic pipette leaving $3 \mathrm{~mm}$ of the opaque interface containing the mononuclear cells. Isotonic phosphate-buffered saline (PBS) was then added, and this was centrifuged at $250 \mathrm{x}$ g for $10 \mathrm{~min}$ for three times to remove any remaining Histopaque 1083 from the mononuclear cells. The peripheral blood mononuclear cells (PBMCs) suspended in isotonic PBS were used for the following assays. Genomic DNA was isolated from the PBMCs using a Wizard ${ }^{\circledR}$ Genomic DNA purification kit (Promega, Madison, WI, USA). DNA from each sample $(4 \mu \mathrm{g})$ was treated with sodium bisulfite (Sigma-Aldrich). nt-MSP analysis was used for the detection of DNA methylation patterns in the FABP4, EC-SOD, MCP-1 and B1 repetitive elements. The first step of nt-MSP used a pair of outer primers, and the second polymerase chain reaction (PCR) step was performed using conventional PCR primers. The primer sequences are listed in Table I.

To reduce misprinting and increase efficiency, nt-MSP was used for amplification. Quantitative (q)PCR analysis was performed with the ABI Prism 7000 Sequence Detection System (Thermo Fisher Scientific, Inc., Waltham, MA, USA). Nested-MSP consisted of two-step PCR amplification after a standard sodium bisulfite DNA modification. The first step used an outer primer pair set that did not contain any $\mathrm{CpG}$. The second PCR step was performed with the conventional PCR primers (Table I). To reduce mispriming and to increase efficiency, touchdown (TD) PCR was used in the amplification, whereby the temperatures are decreased sequentially for each cycle. Samples were subjected to 30 cycles in a TD program $\left(0.5^{\circ} \mathrm{C}\right.$ reduction in temperatures each cycle). After completion of the TD program, 20 cycles were run, ending with a 5 -min extension at $72^{\circ} \mathrm{C}$. The PCR cycling conditions were as follows: $30 \mathrm{TD}$ cycles $\left(0.5^{\circ} \mathrm{C}\right.$ decrease in all temperatures at each cycle) of $94^{\circ} \mathrm{C}$ for $45 \mathrm{sec}$, amplification temperature (Table I) for $45 \mathrm{sec}$, and $72^{\circ} \mathrm{C}$ for $45 \mathrm{sec}$; then 20 cycles of $94^{\circ} \mathrm{C}$ for $45 \mathrm{sec}$, amplification temperature for $45 \mathrm{sec}$ and $72^{\circ} \mathrm{C}$ for $45 \mathrm{sec}$, with a final extension step of $5 \mathrm{~min}$ at $72^{\circ} \mathrm{C}$. The PCR products were separated by electrophoresis in $2 \%$ agarose gel containing ethidium bromide at $120 \mathrm{~V}$ for 20 min. DNA bands were visualized using a ChemiDoc XRS system with Image Lab software, version 4.1 (Bio-Rad Laboratories, Inc., Hercules, CA, USA), and calculated using the following formula: Methylation $(\%)=$ methylation $/($ methylation + unmethylation) x 100 .

Statistical analysis. The results are expressed as the mean \pm standard error of the mean. Data were analyzed using one-way analysis of variance, and additional analyses were performed using the Student Newman-Keuls test for multiple comparisons within treatment groups or a $t$-test for between two groups. The correlation between the SAM/SAH ratio and the methylation levels of the AS-associated genes in the arteries of the $\mathrm{ApoE}^{-/-}$mice were analyzed using Pearson correlation and linear regression analyses. $\mathrm{P}<0.05$ was considered to indicate a statistical significant difference.

\section{Results}

Serum levels of Hcy and atherosclerotic plaque areas in ApoE $^{-/}$mice. To confirm whether the atherosclerotic model was successfully established, the serum levels of Hcy and atherosclerotic plaque areas were measured, as shown in Table II. After 15 weeks, the serum concentrations of Hcy were significantly increased by $1.57-, 3.41$ - and 1.97 -fold in the ApoE ${ }^{-/}$control group, Meth group and Meth-F group, respectively, compared with the normal control group $(\mathrm{P}<0.05$ or $\mathrm{P}<0.01)$. These data suggested that a high-methionine diet induced HHcy in the $\mathrm{ApoE}^{-/-}$mice. However, the serum concentration of Hcy was decreased by $42.3 \%$ in the Meth-F group, compared with the Meth group $(\mathrm{P}<0.05)$, which indicated that folate and vitamin $\mathrm{B}_{12}$ modulated the effect caused by the high methionine diet.

The atherosclerotic lesions were examined and analyzed using a cross-sectional stereological method for the aortic root, as shown in Fig. 1 and Table II. Compared with the normal control group, the sizes of the atherosclerotic lesions were significantly increased in the $\mathrm{n} \mathrm{ApoE}^{-/}$control group, Meth group and Meth-F group $(\mathrm{P}<0.05$ or $\mathrm{P}<0.01)$. However, the area of the atherosclerotic lesions was decreased by $39.4 \%$ in the Meth-F group, compared with the Meth group, $(\mathrm{P}<0.05)$. The atherosclerotic lesions in the Meth group were the most severe and widespread, which suggested HHcy may have had an effect in accelerating the development of AS, whereas folate and vitamin $\mathrm{B}_{12}$ modulated the effect of HHcy on the formation of atherosclerotic plaques $(19,20)$.

Serum concentrations of SAM and SAH, measured using $H P L C$, in mice. SAM and SAH are intermediates of methionine metabolism and, for the majority of cellular methyltransferase reactions, SAM is a priority for one-carbon metabolism as the methyl donor. SAM is converted to $\mathrm{SAH}$ within the active site of the methyltransferase by transfer of the methyl group (22). As shown in the diagram in Fig. 2, the serum concentrations of SAM and SAH were detected, and the ratio of SAM/SAH was calculated. After 15 weeks on the experimental diets, the concentrations of SAM were increased by 3.02-, 3.42- and 2.46-fold in the $\mathrm{ApoE}^{-/-}$control group, Meth group and Meth-F group, respectively, compared with the normal control group $(\mathrm{P}<0.05$ or $\mathrm{P}<0.01)$. In addition, the serum concentrations of SAH were 1.08-fold higher in the Meth group, compared with the normal control group $(\mathrm{P}<0.05)$. By contrast, the ratio of $\mathrm{SAM} / \mathrm{SAH}$, compared with the normal control group, was 
Table I. Primer sequences of FABP4, EC-SOD, MCP-1 and B1 repetitive elements.

\begin{tabular}{|c|c|c|c|}
\hline Primer set & Primer sequence $\left(5^{\prime} \rightarrow 3^{\prime}\right)$ & Size (bp) & $\begin{array}{l}\text { Amplification } \\
\text { temperature }\left({ }^{\circ} \mathrm{C}\right)\end{array}$ \\
\hline FABP4-O & $\begin{array}{l}\text { F: ATTTTATTAGGGAGAGAAGGAAAAA } \\
\text { R: TCACATCTCAAAATCTAAAACTAAC }\end{array}$ & 134 & 60.7 \\
\hline FABP4-M & $\begin{array}{l}\text { F: AAGTTGGAAGTTTTTTTTGTTAACG } \\
\text { R: CCTTTACCTATATTTAGTCTTTCGAA }\end{array}$ & 150 & 60.9 \\
\hline FABP4-U & $\begin{array}{l}\text { F: AGTTGGAAGTTTTTTTTGTTAATGG } \\
\text { R: TTTACCTATATTTACTTCTTTCAAA }\end{array}$ & 140 & 60.9 \\
\hline EC-SOD-O & $\begin{array}{l}\text { F: TTTTTGAATAGAATGAAGAGGGTGTA } \\
\text { R: AACCAAATCAAAATTTCAATCATAAA }\end{array}$ & 543 & 55.4 \\
\hline EC-SOD-M & $\begin{array}{l}\text { F: AGTAATGATGGAGAGGTTAGGTTTC } \\
\text { R: AAATAAAACAAAAAAAACACTCGTA }\end{array}$ & 110 & 64.0 \\
\hline EC-SOD-U & $\begin{array}{l}\text { F: GTAATGATGGAGAGGTTAGGTTTTG } \\
\text { R: AAAATAAAACAAAAAAAACACTCATA }\end{array}$ & 110 & 64.0 \\
\hline MCP-1-O & $\begin{array}{l}\text { F: TTGTTGAAATGAATTTTAAGGGTTT } \\
\text { R: CCCAAATAACTCCAACCTAACTATC }\end{array}$ & 140 & 50.0 \\
\hline MCP-1-M & $\begin{array}{l}\text { F: TTTAAGGGTTTTTAGATTTTATCGT } \\
\text { R: AACTCTCTACCCTATTTCCTTCGTA }\end{array}$ & 137 & 61.6 \\
\hline MCP-1-U & $\begin{array}{l}\text { F: TTTAAGGGTTTTTAGATTTTATTGT } \\
\text { R: AACTCTCTACCCTATTTCCTTCATA }\end{array}$ & 145 & 61.6 \\
\hline B1-O & $\begin{array}{l}\text { F: ATAGAAGTGGATGTTTATAGTTAGTTATTG } \\
\text { R: CACTCCAACTTTTTAACCCTAAC }\end{array}$ & 269 & 64.7 \\
\hline B1-M & $\begin{array}{l}\text { F: GTTAGTTATTGGATGGGTTATACGG } \\
\text { R: TACAACTAAAAACAAAAACTCCGAA }\end{array}$ & 139 & 62.1 \\
\hline B1-U & $\begin{array}{l}\text { F: GTTAGTTATTGGATGGGTTATATGG } \\
\text { R: TACAACTAAAAACAAAAACTCCAAA }\end{array}$ & 139 & 62.1 \\
\hline
\end{tabular}

FABP, fatty acid binding protein; EC-SOD, extracellular superoxide dismutase; MCP-1, monocyte chemoattractant protein-1; O, outer primer; $\mathrm{M}$, methylated primer; U, unmethylated primer; F, forward; R, reverse.

increased by 1.67- and 2.75-fold in the $\mathrm{ApoE}^{-/-}$control group and Meth group, respectively $(\mathrm{P}<0.05$ or $\mathrm{P}<0.01)$. These data indicated that the atherogenic diets caused a parallel increase in the levels of SAM and SAH, and the SAM/SAH ratio.

DNA methylation levels of $B 1$ repetitive elements, FABP4, $E C-S O D$ and $M C P-1$, and their correlation with SAM, SAH and $S A M / S A H$. To confirm whether the methylation levels of the AS-associated genes were correlated with the ratio of SAM/SAH, the present study measured the methylation levels of $\mathrm{B} 1$ repetitive elements, FABP4, EC-SOD and MCP-1. As shown in Fig. 3A, the methylation levels of the B1 repetitive elements were decreased by $40 \%$ in the Meth group, compared with the normal control group $(\mathrm{P}<0.05)$, however, the methylation levels of the $\mathrm{B} 1$ repetitive elements were increased by 1.54 -fold in the Meth-F group. These data indicated that the $\mathrm{B} 1$ repetitive elements were hypomethylated, which accounted for the majority of gene transcription activity in the pathogenesis of AS, induced by HHcy. The levels of B1 methylation were negatively correlated with levels of SAH $(P=0.0212 ; \gamma=-0.3634)$; However, as shown in Fig. 3D, there was a positive correlation between the methylation levels of the $\mathrm{B} 1$ repetitive elements and the ratio of $\mathrm{SAM} / \mathrm{SAH}(\mathrm{P}=0.0210$; $\gamma=-0.3638)$. The B1 methylation levels were correlated with the concentration of serum SAM; however, the results showed that the correlation between the B1 methylation levels and the $\mathrm{SAM} / \mathrm{SAH}$ ratio was more marked.

FABP4 is important in metabolic deterioration and the development of AS (23). As shown in Fig. 4A, the methylation levels of FABP4 detected by nt-MSP decreased by $5.02 \%$ in the Meth group, compared with the normal control group $(\mathrm{P}<0.05)$. In addition, FABP4 methylation levels were negatively correlated with the ratio of SAM/SAH $(\mathrm{P}=0.00158$; $\gamma=-0.3792)$. These findings indicated that FABP4, a crucial gene in lipid metabolism and inflammatory reactions exhibited with hypomethylation in the AS model induced by HHcy.

EC-SOD regulates baseline cardiac morphology and protects the heart from fibrosis, apoptosis and loss of function following oxidative injury caused by HHcy (24). As shown in Fig. 5A the methylation status of EC-SOD showed marked hypermethylation. Compared with the normal control group, the methylation of EC-SOD in the Meth group was increased by 1.08 -fold $(\mathrm{P}<0.05)$. Additionally, as shown in Fig. $5 \mathrm{D}$, the methylation levels of EC-SOD were significantly negatively correlated with the ratio of SAM/SAH $(\mathrm{P}=0.0117 ; \gamma=-0.3949)$.

MCP-1 is important in inflammation and is a basic mediator in a biological system, which is valuable in the formation of AS (25). Following feeding with the respective experimental diets for 15 weeks, the status of MCP-1 exhibited hypomethylation in the PBMCs. In the Meth group, the methylation levels were 
Table II. Serum levels of Hcy and atherosclerotic lesion area.

\begin{tabular}{lcr} 
Group & Hcy $(\mu \mathrm{mol} / \mathrm{l})$ & Atherosclerotic lesion area \\
\hline Normal control & $6.51 \pm 0.21$ & 0 \\
ApoE $^{-/}$control & $10.25 \pm 0.86^{\mathrm{a}}$ & $3.99 \pm 0.45^{\mathrm{b}}$ \\
Meth & $22.22 \pm 1.54^{\mathrm{b}}$ & $6.22 \pm 0.49^{\mathrm{b}}$ \\
Meth-F & $12.82 \pm 1.80^{\mathrm{c}}$ & $4.41 \pm 0.57^{\mathrm{c}}$
\end{tabular}

Values are presented as the mean \pm standard error of the mean $(\mathrm{n}=12) .{ }^{\mathrm{a}} \mathrm{P}<0.05$ and ${ }^{\mathrm{b}} \mathrm{P}<0.01$, compared with the normal control group; ${ }^{\mathrm{c}} \mathrm{P}<0.01$, compared with the Meth group. Normal control group, wild-type mice fed a regular diet; $\mathrm{ApoE}^{-/-}$control group, ApoE ${ }^{-/-}$mice fed a regular diet; Meth group, ApoE ${ }^{-/}$mice fed a high-methionine diet; Meth-F group, ApoE ${ }^{-/}$mice fed a high-methionine diet containing folic acid and vitamin $\mathrm{B}_{12}$. ApoE, apolipoprotein E; Hcy, homocysteine.

decreased by $6.18 \%$, compared with the normal control group $(\mathrm{P}<0.05)$, as shown in Fig. 6A. In investigating the association between MCP-1 methylation and SAM/SAH ratio, a negative correlation was found $(\mathrm{P}=0.0496 ; \gamma=-0.3125)$.

Taken together, the data of the present study indicated that there was a marked correlation between the SAM/SAH ratio and the methylation levels of atherosclerotic-associated genes, which were considered a biomarker of AS. These findings provided evidence that the ratio of SAM/SAH may be a more sensitive indictor for AS.

\section{Discussion}

Numerous epidemiological investigations and case-control studies have demonstrated that elevated plasma Hcy is associated with an increased risk of vascular disease (26-28). However, other case-control studies have not demonstrated such a causal association, and the mechanism of Hcy-induced AS remains to be fully elucidated (29,30). In addition, whether Hcy itself is a major factor or an indirect metabolic marker of certain biochemical processes, which occur in AS is unclear. The present study aimed to identify an effective and reliable biomarker of Hcy-induced AS.

In the processes of methionine metabolism, there are several byproducts, including Hcy, SAM and SAH, and previous studies have demonstrated that alterations in the $\mathrm{SAM} / \mathrm{SAH}$ ratio may be more directly associated with vascular damage, compared with Hcy or the other intermediates (31-33). A number of studies have described that increased levels of Hcy are always followed by higher concentrations of $\mathrm{SAH}$, and it may be an important mediator of toxicity in the body. In addition, the SAM/SAH ratio is considered to be an indicator of the transfer of methyl groups from SAM to the numerous methyl acceptors in cells, and thereby reflects its methylation potential (34). The significance of this observation is associated with the hypothesis that SAM and SAH may be key components in the pathophysiology of the Hcy-vascular disease axis. Although the hypothesis that Hcy is directly linked to damage in the vascular endothelium has not been validated, studies have suggested that there is an association between the SAM/SAH ratio and vascular injury, and a decrease in the SAM/SAH ratio is often regarded as an indicator of reduced cellular methylation capacity (35). In the present study, ApoE ${ }^{-/-}$mice were fed a high methionine diet, and it was found that the serum concentrations of Hcy were increased, particularly in the Meth group. Compared with the normal group, the serum concentrations of Hcy were increased by 1.15-, 2.54- and 1.17-fold in the $\mathrm{ApoE}^{-/-}$control group, Meth group and Meth-F group, respectively. In addition, as the concentration of Hcy increased, the atherosclerotic lesion was more severely widespread. The present study also found that folate and vitamin $B_{12}$ suppressed the effect of Hcy-induced AS, and the sizes of the atherosclerotic lesions were significantly increased in the $\mathrm{ApoE}^{-/}$control group, Meth group and Meth-F group, by up to 1.44-, 2.40- and 1.45-fold, respectively, compared with those of the normal control group. Taken together, these data suggested that establishment of the AS model induced by HHcy was successful. As the intermediates of methionine metabolism, the concentrations of SAM and SAH also increased, as did the ratio of SAM/SAH.

Several studies have confirmed that alterations in the methylation levels of specific genes are usually associated with the occurrence and development of cancer (36). AS is similar to cancer in certain aspects and has been referred to as a cancer-like disease $(37,38)$; AS and cancer are chronic and progressive, and the inducing factors are very similar. In addition, the pathological mechanisms are similar, involving genetic and environmental elements. In the present study, the methylation statuses of specific genes associated with AS were examined. Cash et al (39) first suggested that DNA hypomethylation is involved in the development of cardiovascular disease, and evidence from animal studies has suggested that global DNA hypomethylation is associated with atherosclerotic lesions. A number of previous reports have focused on alterations in the DNA methylation of specific genes associated with AS $(40,41)$. Global hypomethylation affects $\mathrm{CpG}$ dinucleotides in repetitive elements and in certain gene-specific promoter $\mathrm{CpG}$ islands (42). In the present study, it was found that the methylation levels of pivotal AS-associated genes were altered. B1 repetitive elements are the sequences of short interspersed nucleotide elements in mice, corresponding to the Alu sequence in humans (19). Increasing evidence suggests that $\mathrm{B} 1$ repetitive element hypomethylation is associated with gene transcriptional activity in the pathogenesis of cardiovascular diseases, particularly AS (43). In the present study, it was also found that $\mathrm{B} 1$ repetitive elements exhibited hypomethylation in the blood cells of the AS model. FABP4 has been identified as a potential circulation marker for metabolic syndrome, 

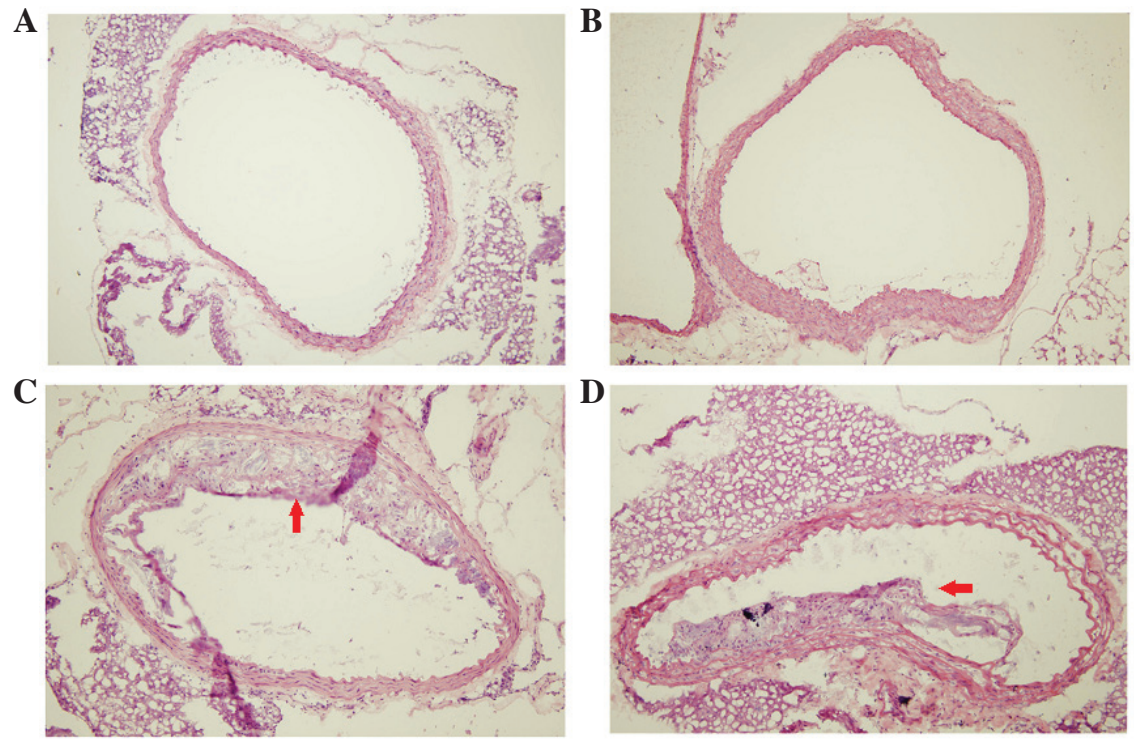

Figure 1. Morphological features of a representative cross section of the aortic root, stained with hematoxylin and eosin (magnification, x100). Cross sections of the hematoxylin and eosin-stained aortic roots were analyzed, according to the methods of Jiang et al (19) and Zulli et al (20). Arrows indicate the presence of atherosclerotic lesions. (A) Normal control group; (B) $\mathrm{ApoE}^{-/}$control group comprising $\mathrm{ApoE}^{-/}$mice fed a regular diet; (C) Meth group comprising $\mathrm{ApoE}^{-/}$mice fed a high-methionine diet (D) Meth-F group comprising $\mathrm{ApoE}^{--}$mice fed a high-methionine diet containing folic acid and vitamin $\mathrm{B}_{12}$. ApoE, apolipoprotein E.
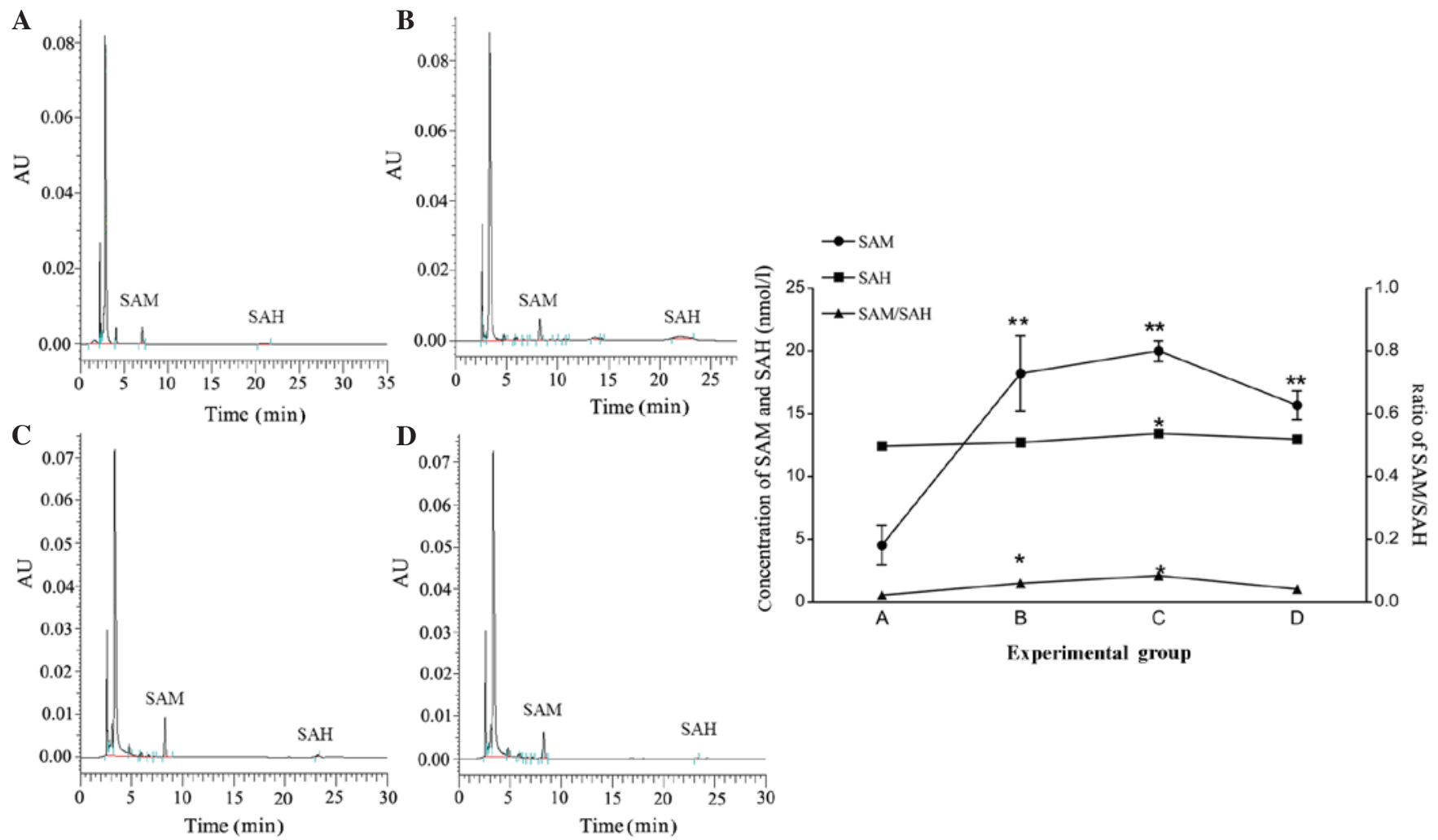

Figure 2. Serum concentrations of SAM and SAH in $\mathrm{ApoE}^{-/}$mice. Serum concentrations of SAM and SAH were detected using high-performance liquid chromatography. In addition, the ratio of SAM/SAH was analyzed. The graph on the right shows the statistical results of the concentrations of SAM, SAH and their ratio. The results are presented as the mean \pm standard error of the mean. ${ }^{*} \mathrm{P}<0.05$ and ${ }^{* *} \mathrm{P}<0.01$, vs. normal control group. (A) Normal control group; (B) $\mathrm{ApoE}^{-/}$control group comprising $\mathrm{ApoE}^{-/}$mice fed a regular diet; (C) Meth group comprising ApoE ${ }^{-/}$mice fed a high-methionine diet (D) Meth-F group comprising $\mathrm{ApoE}^{-/}$mice fed a high-methionine diet containing folic acid and vitamin $\mathrm{B}_{12}$. ApoE, apolipoprotein E; SAM, S-adenosylmethionine; SAH, S-adenosylhomocysteine.

and is increased in individuals with diabetes and metabolic syndrome due to the development of subclinical inflammation, which leads to AS (44). The present study is the first, to the best of our knowledge to report that the methylation levels of FABP4 were closely associated with AS. EC-SOD protects arteries against the deleterious effects of superoxide anions 
A

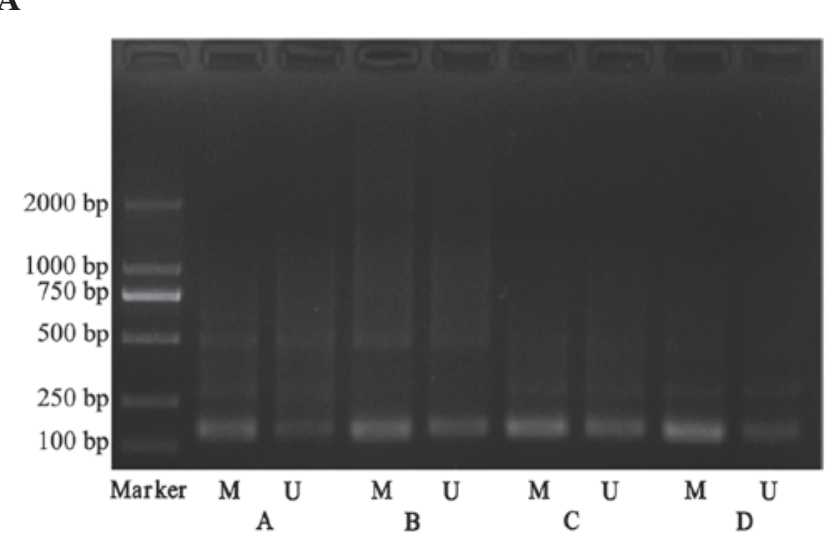

B

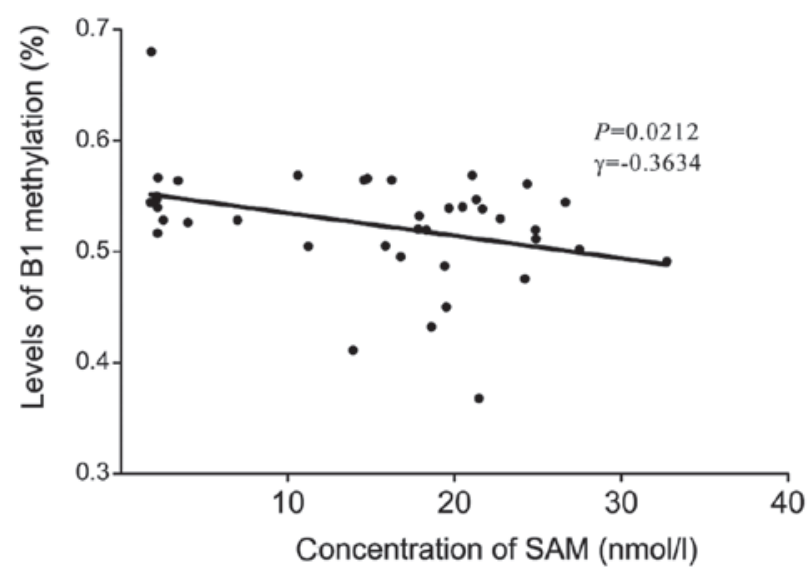

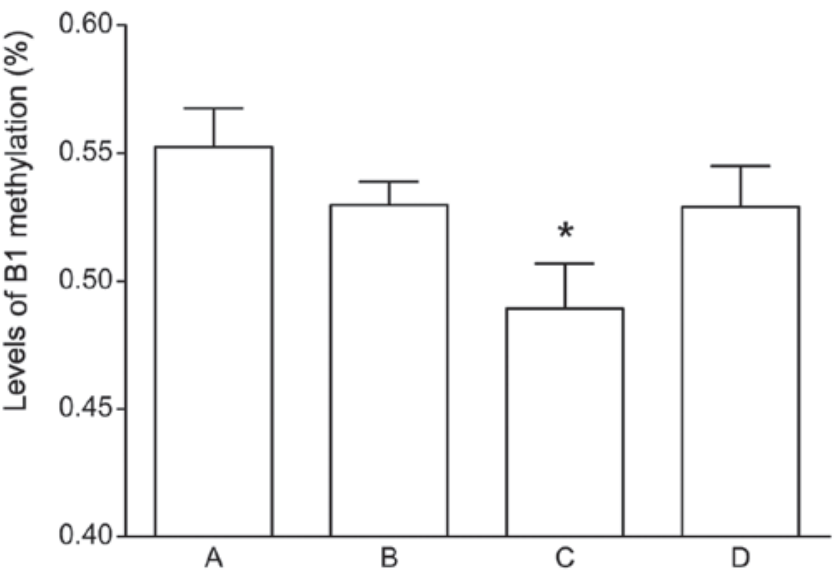

C

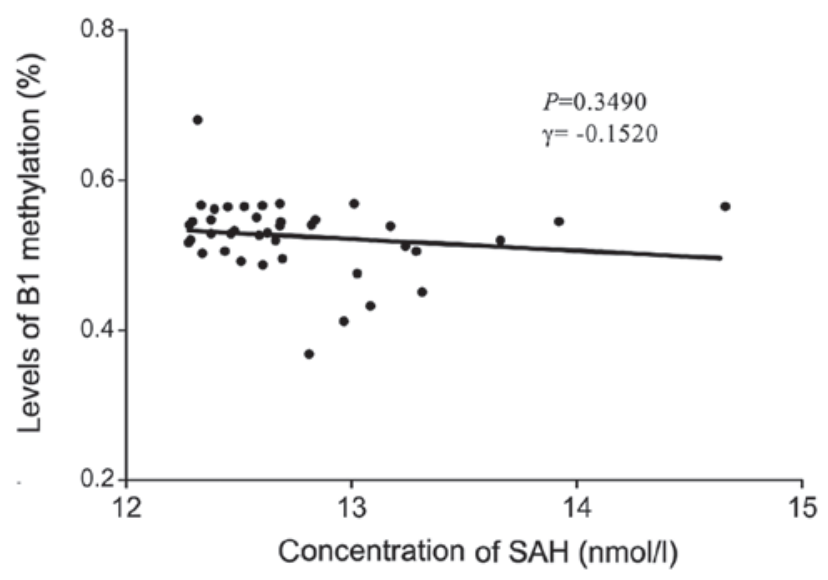

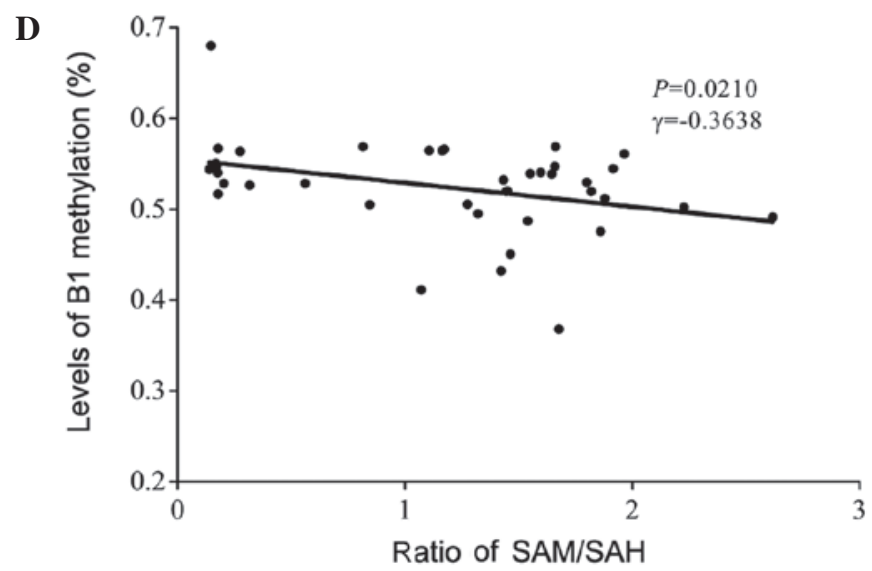

Figure 3. Methylation of B1 repetitive elements, concentrations of serum SAM and SAH, and their correlation. (A) Methylation levels of B1 repetitive elements were detected using nested touchdown-methylation specific polymerase chain reaction analysis. Concentrations of serum (B) $\mathrm{SAM}$ and (C) SAH were measured using high-performance liquid chromatography. (D) Correlation between B1 methylation and SAM/SAH ratio. Results are presented as the mean \pm standard error of the mean. ${ }^{*} \mathrm{P}<0.05$, vs. normal control group. (A) Normal control group; (B) ApoE ${ }^{-/-}$control group of ApoE ${ }^{-/-}$mice fed a regular diet; (C) Meth group of ApoE ${ }^{-/}$mice fed a high-methionine diet (D) Meth-F group of ApoE ${ }^{-/}$mice fed a high-methionine diet containing folic acid and vitamin $\mathrm{B}_{12}$. ApoE, apolipoprotein E; SAM, S-adenosylmethionine; SAH, S-adenosylhomocysteine; M, methylated primer; U, unmethylated primer.

and the development of AS. Laukkanen et al (45) reported that the altered methylation of EC-SOD is associated with the development of AS, and suggested that it may affect the structures and functions of EC-SOD and other genes, which may be involved in the development of atherosclerotic lesions in mice. The present study found that EC-SOD was hypermethylated, particularly in the Meth group; the methylation of EC-SOD was increased by 1.08-fold, compared with that in the normal control group. It has been reported that $\mathrm{CpG}$ site hypometh- ylation in the MCP-1 promoter region may be important in the AS of type 2 diabetes (18). The present study also found that, in the Meth group, MCP-1 was hypomethylated, and the methylation levels were decreased by $6.18 \%$, compared with the normal control group. Therefore it was hypothesized that the DNA methylation levels of FABP4, EC-SOD, MCP-1 and B1 repetitive elements may be an indicator of AS.

Several studies investigating biomarkers of AS have been performed, and have reported that Hcy may be a sensitive 

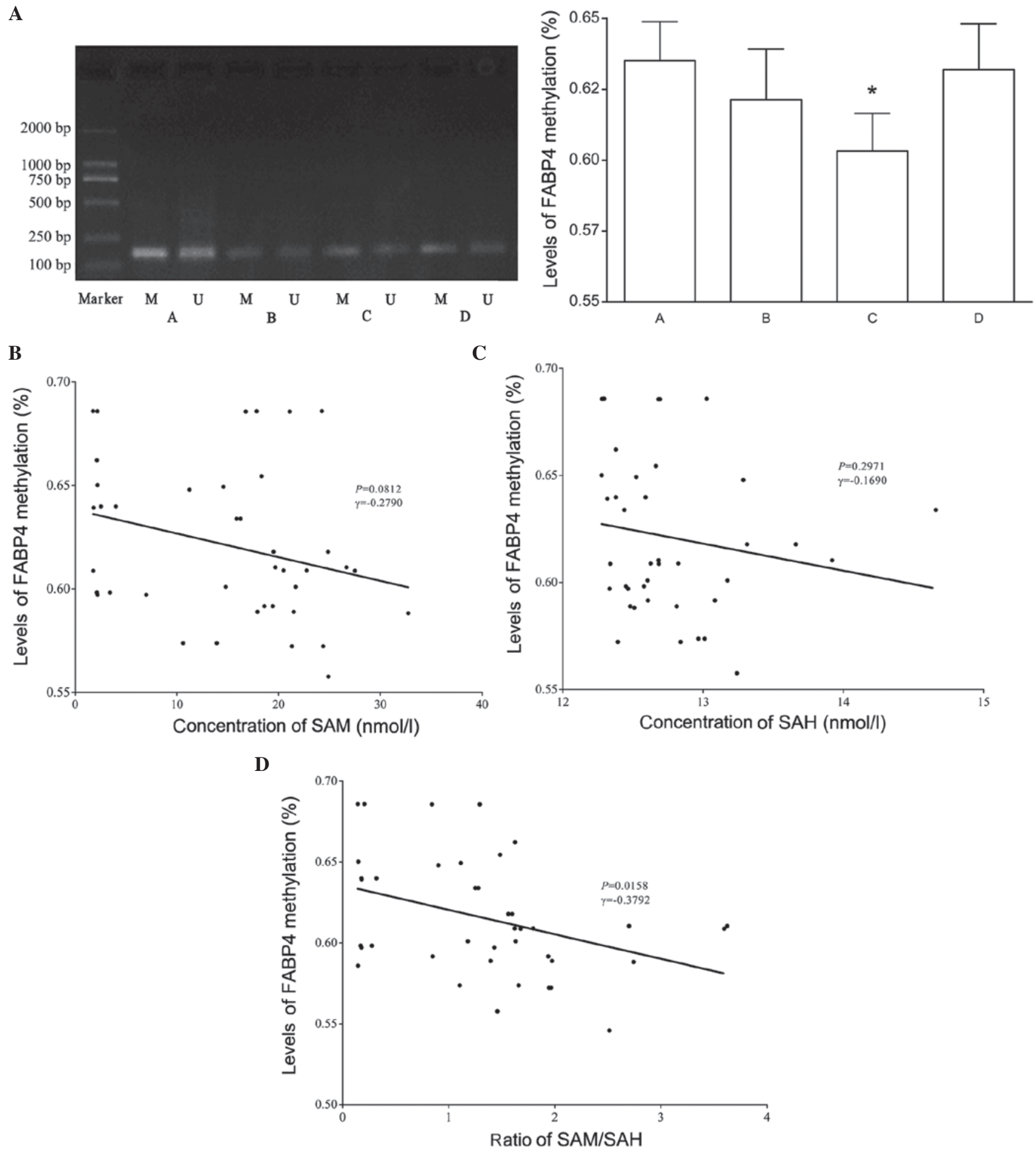

Figure 4. Methylation of FABP4, concentrations of serum SAM and SAH, and correlation analysis. (A) Methylation levels of FABP4 were detected using nested touchdown-methylation specific polymerase chain reaction analysis. Concentrations of serum (B) SAM and (C) SAH were measured using high-performance liquid chromatography. (D) Correlation of FABP4 methylation levels and SAM/SAH ratio. Results are presented as the mean \pm standard error of the mean. ${ }^{*} \mathrm{P}<0.05$, vs. normal control group. (A) Normal control group; (B) $\mathrm{ApoE}^{-/}$control group of $\mathrm{ApoE}^{-/}$mice fed a regular diet; (C) Meth group of ApoE $\mathrm{E}^{-/}$mice fed a high-methionine diet (D) Meth-F group of $\mathrm{ApoE}^{-/-}$mice fed a high-methionine diet containing folic acid and vitamin $\mathrm{B}_{12}$. ApoE, apolipoprotein E; SAM, S-adenosylmethionine; SAH, S-adenosylhomocysteine; FABP, fatty acid binding protein. M, methylated primer; U, unmethylated primer.

biomarker for AS (46-48). It has also been reported that plasma $\mathrm{SAH}$ is a more sensitive marker of clinical cardiovascular disease than plasma Hcy (49). However, the data of the present study suggested that the SAM/SAH ratio may be a more sensitive biomarker of AS. By causing feedback inhibition of SAM-dependent methyltransferases, the accumulation of SAH can affect the DNA methylation pattern and lead to the promotion of chronic diseases, and the SAM/SAH ratio is the prime regulator of the activities of the majority of methyltransferases in the cell (50). SAH is the metabolic precursor of Hcy in a reaction which catalyzes SAM by SAH hydrolase. Due to this reaction, changes in the concentrations of SAM and SAH are 
A

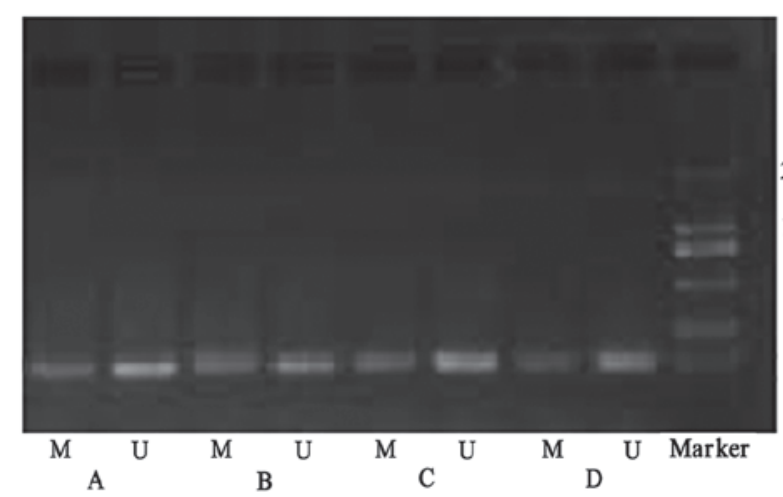

B

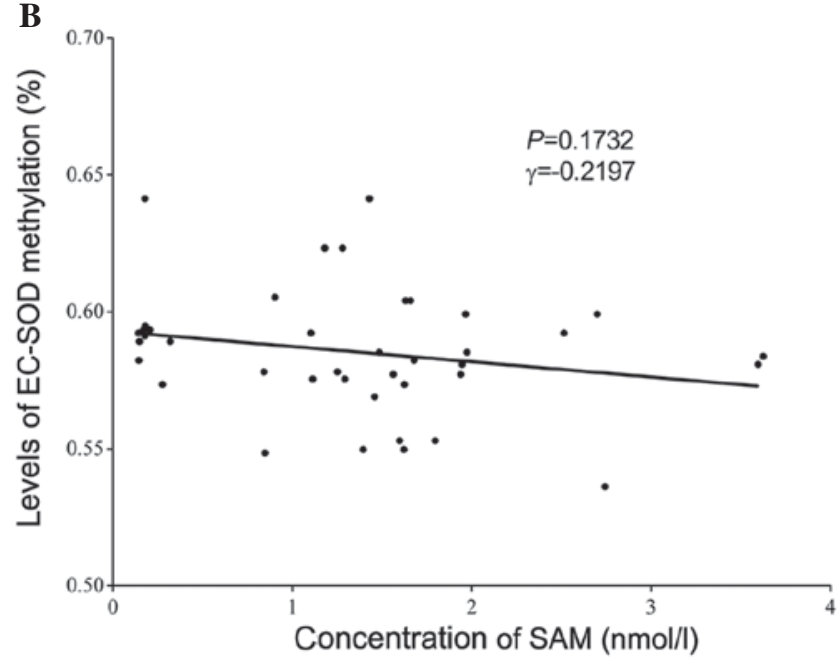

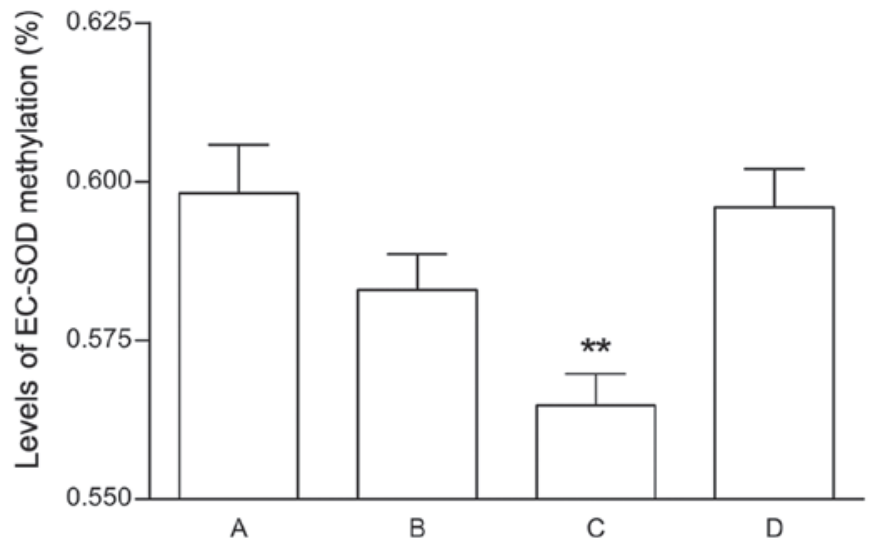

C

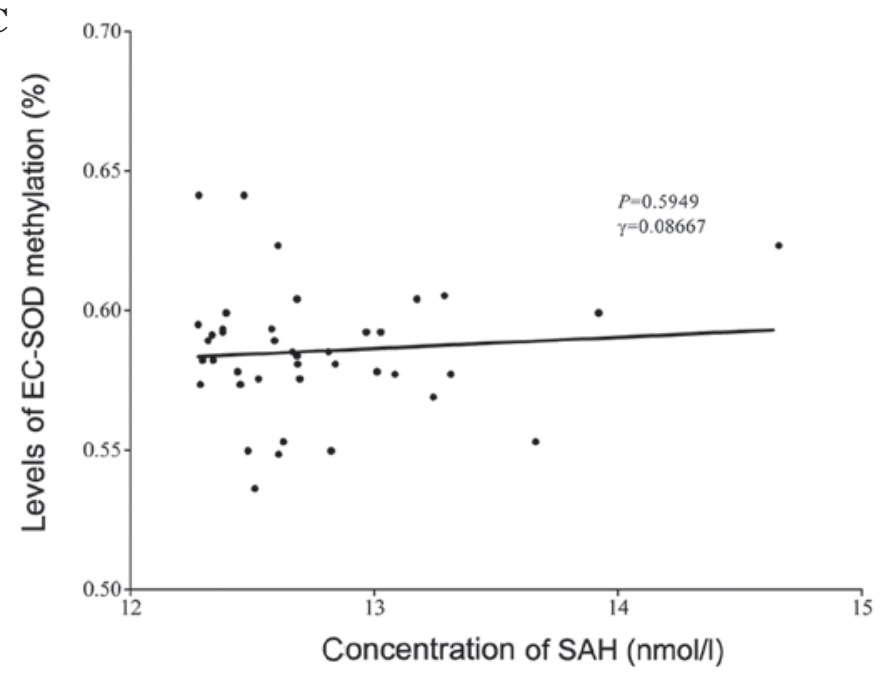

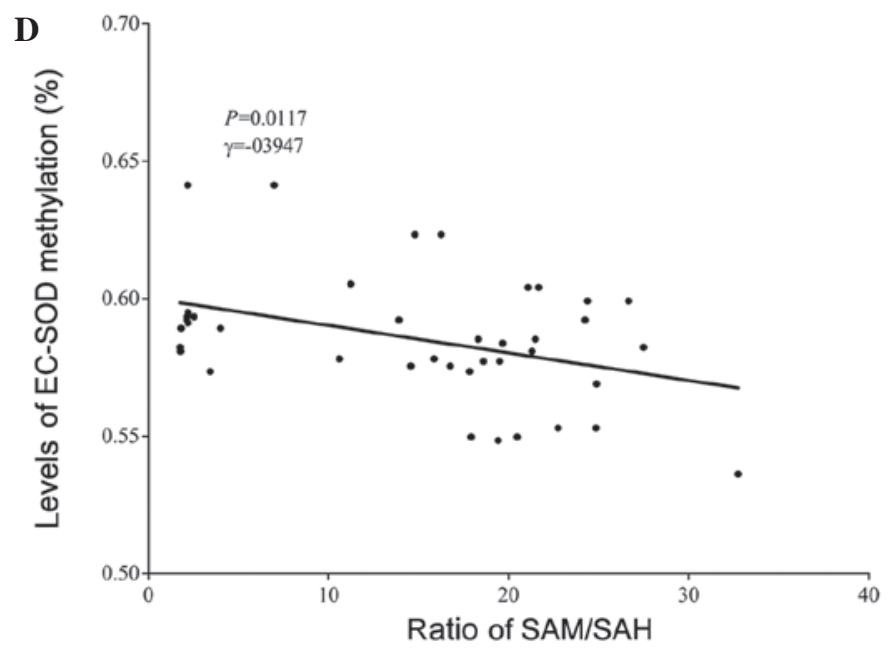

Figure 5. Methylation of EC-SOD, concentrations of serum SAM and SAH, and correlation analysis. (A) Methylation levels of EC-SOD were analyzed using nested touchdown-methylation specific polymerase chain reaction analysis. Concentrations of serum (B) SAM and (C) SAH were measured using high-performance liquid chromatography. (D) Correlation of EC-SOD methylation levels and SAM/SAH ratio. Results are presented as the mean \pm standard

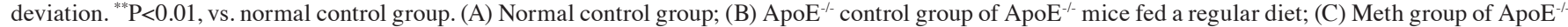
mice fed a high-methionine diet (D) Meth-F group of $\mathrm{ApoE}^{-/-}$mice fed a high-methionine diet containing folic acid and vitamin $\mathrm{B}_{12}$; ApoE, apolipoprotein $\mathrm{E}$; SAM, S-adenosylmethionine SAH, S-adenosylhomocysteine; EC-SOD, extracellular superoxide dismutase. M, methylated primer; U, unmethylated primer.

always equal, but the ratio usually does not change significantly. A study by Loehrer et al (10) described the levels of SAH in the plasma following an oral load of SAM and following an oral load of methionine. In the present study, SAM and SAH concentrations were determined by HPLC. Serum Hcy concentrations were measured by an automatic biochemical analyzer. HPLC has high sensitivity and accuracy, and so the ratio of S-adenosylmethionine to S-adenosylhomocysteine can be used as early diagnostic indicators. Therefore, the present study performed correlation analyses of FABP4, EC-SOD, MCP-1 and $\mathrm{B} 1$ repetitive elements, respectively, with serum levels of SAM and SAH, and the SAM/SAH ratio, to confirm 
A

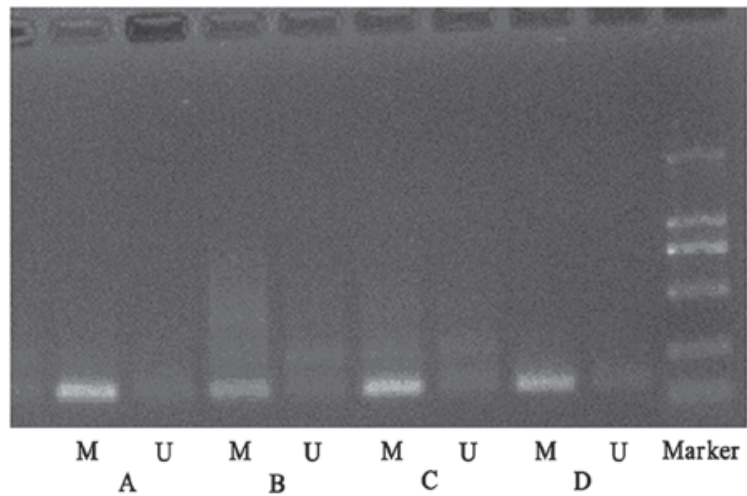

B

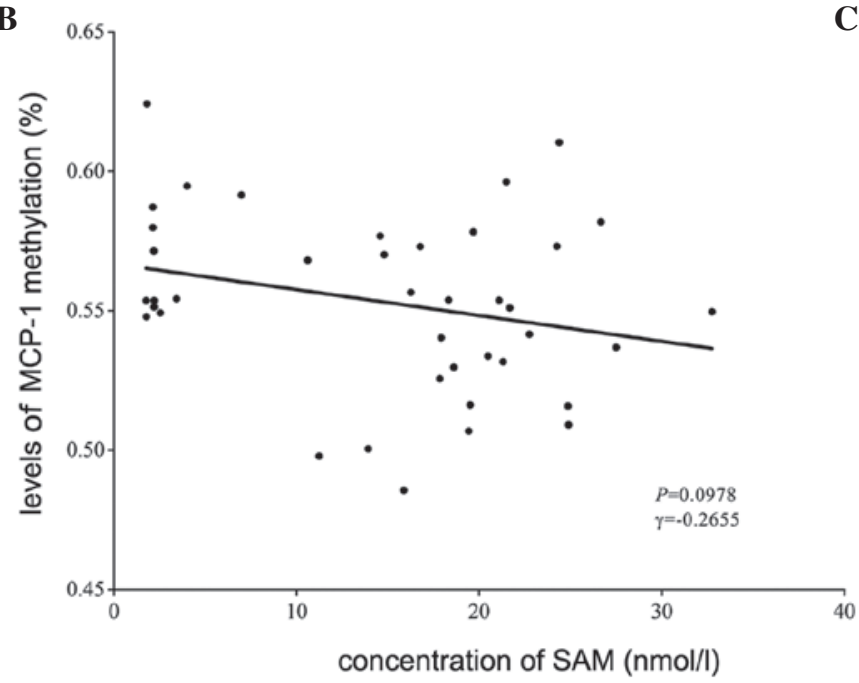

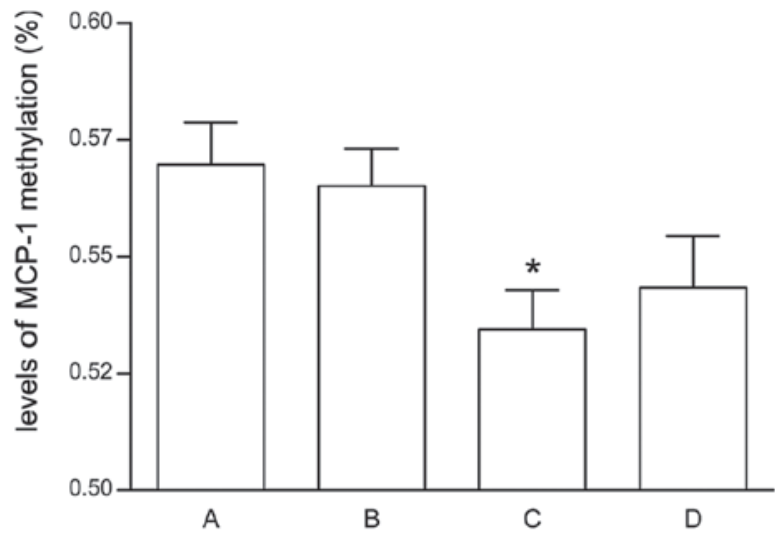

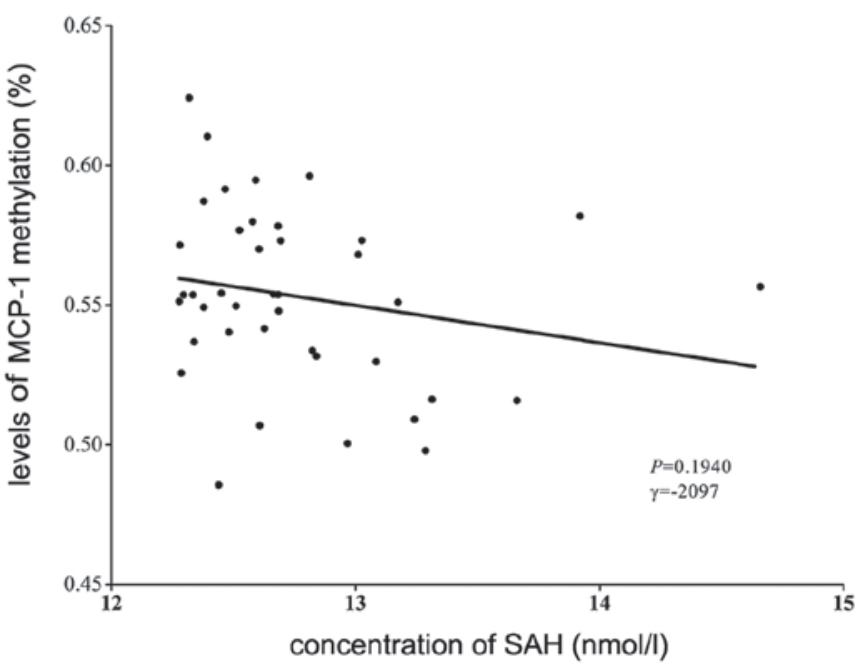

D

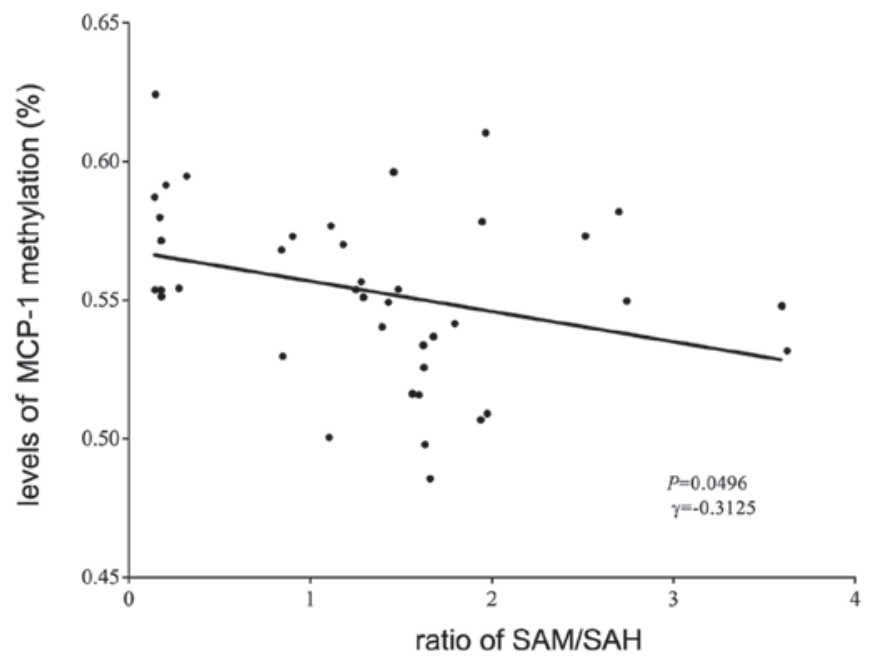

Figure 6. Methylation of MCP-1, concentrations of serum SAM and SAH and correlation analysis. (A) Methylation levels of MCP-1 were analyzed using nested touchdown-methylation specific polymerase chain reaction analysis. Concentrations of serum (B) SAM and (C) SAH were measured using high-performance liquid chromatography. (D) Correlation of MCP-1 methylation levels and SAM/SAH ratio. Results are presented as the mean \pm standard error of the mean. ${ }^{*} \mathrm{P}<0.05$, vs. normal control group. (A) Normal control group; (B) ApoE ${ }^{-/-}$control group of ApoE ${ }^{-/-}$mice fed a regular diet; (C) Meth group of ApoE $\mathrm{E}^{-/-}$mice fed a high-methionine diet (D) Meth-F group of $\mathrm{ApoE}^{-/-}$mice fed a high-methionine diet containing folic acid and vitamin $\mathrm{B}_{12}$; ApoE, apolipoprotein E; SAM, S-adenosylmethionine SAH, S-adenosylhomocysteine; MCP-1, monocyte chemoattractant protein-1. M, methylated primer; U, unmethylated primer.

which is the optimal biomarker of AS. The results of the present study showed that the methylation levels of these AS-associated genes were significantly correlated with the ratio of SAM/SAH in the $\mathrm{ApoE}^{-/}$mice.

In conclusion, FABP4, EC-SOD and MCP-1 are important in the formation and/or development of AS, and previous studies have confirmed that DNA methylation is a diagnostic biomarker of AS (51-53). On this basis, the present study analyzed the correlation between DNA methylation of FABP4, EC-SOD, MCP-1, and B1 repetitive elements and the serum SAM/SAH ratio to confirm the hypothesis that the serum SAM/SAH ratio may be a more sensitive biomarker of AS, and 
may be used for the clinical diagnosis of AS. Further investigations are required to support and confirm this conclusion, to determine its potential for clinical usage.

\section{Acknowledgements}

This study was supported by grants from the National Natural Science Foundation of China (grant nos. 81160044, 81260105 and 81260063), the Colleges and Universities Focus on Science and Technology research projects (grant no. NGY2010039) and the Ning Xia Science and Technique project (grant no. 20100820).

\section{References}

1. Segers D, Lipton JA, Leenen PJ, Cheng C, Tempel D, Pasterkamp G, Moll FL, de Crom R and Krams R: Atherosclerotic plaque stability is affected by the chemokine CXCL10 in both mice and humans. Int J Inflam 2011: 936109, 2011.

2. Orbay H, Hong H, Zhang Y and Cai W: Positron emission tomography imaging of atherosclerosis. Theranostics 3: 894-902, 2013.

3. Ma S, Zhang H, Sun W, Gong H, Wang Y, Ma C, Wang J, Cao C, Yang X, Tian J and Jiang Y: Hyperhomocysteinemia induces cardiac injury by up-regulation of p53-dependent Noxa and Bax expression through the p53 DNA methylation in $\mathrm{ApoE}^{-/-}$mice. Acta Biochim Biophys Sin (Shanghai) 45: 391-400, 2013

4. Green TJ, Skeaff CM, McMahon JA, Venn BJ, Williams SM, Devlin AM and Innis SM: Homocysteine-lowering vitamins do not lower plasma S-adenosylhomocysteine in older people with elevated homocysteine concentrations. Br J Nutr 103: 1629-1634, 2010.

5. Pizzolo F, Blom HJ, Choi SW, Girelli D, Guarini P, Martinelli N, Stanzial AM, Corrocher R, Olivieri O and Friso S: Folic acid effects on s-adenosylmethionine, s-adenosylhomocysteine, and DNA methylation in patients with intermediate hyperhomocysteinemia. J Am Coll Nutr 30: 11-18, 2011.

6. Ma SL, Tang NL and Lam LC: Association of gene expression and methylation of UQCRC1 to the predisposition of Alzheimer's disease in a Chinese population. J Psychiatr Res 76: 143-147, 2016.

7. Sipkens JA, Hahn NE, Blom HJ, Lougheed SM, Stehouwer CD, Rauwerda JA, Krijnen PA, van Hinsbergh VW and Niessen HW: S-Adenosylhomocysteine induces apoptosis and phosphatidylserine exposure in endothelial cells independent of homocysteine. Atherosclerosis 221: 48-54, 2012.

8. Tehlivets O: Homocysteine as a risk factor for atherosclerosis: Is its conversion to s-adenosyl-L-homocysteine the key to deregulated lipid metabolism? J Lipids 2011: 702853, 2011.

9. Kerins DM, Koury MJ, Capdevila A, Rana S and Wagner C: Plasma S-adenosylhomocysteine is a more sensitive indicator of cardiovascular disease than plasma homocysteine. Am J Clin Nutr 74: 723-729, 2001

10. Loehrer FM, Schwab R, Angst CP, Haefeli WE and Fowler B: Influence of oral S-adenosyl-methionine on plasma 5-methyltetrahydrofolate, S-adenosylhomocysteine, homocysteine and methionine in healthy humans. J Pharmacol Exp Ther 282: 845-850, 1997.

11. Loehrer FM, Haefeli WE, Angst CP, Browne G, Frick G and Fowler B: Effect of methionine loading on 5-methyltetrahydrofolate, 5-adenosyl-methionine and S-adenosylhomocysteine in plasma of healthy humans. Clin Sci 91: 79-86, 1996.

12. Loehrer FM, Angst CP, Brunner FP, Haefeli WE and Fowler B: Evidence for disturbed S-adenosylmethionine: $\mathrm{S}$-adenosylhomocysteine ratio in patients with end-stage renal failure: A cause for disturbed methylation reactions? Nephrol Dial Transplant 13: 656-661, 1998.

13. Meehan RR and Stancheva I: DNA methylation and control of gene expression in vertebrate development. Essays Biochem 37: 59-70, 2001.

14. Chen NC, Yang F, Capecci LM, Gu Z, Schafer AI, Durante W, Yang XF and Wang H: Regulation of homocysteine metabolism and methylation in human and mouse tissues. FASEB J 24: 2804-2817, 2010
15. Bird A: DNA methylation patterns and epigenetic memory. Genes Dev 16: 6-21, 2002.

16. Fukushige $\mathrm{S}$ and Horii A: DNA methylation in cancer: A gene silencing mechanism and the clinical potential of its biomarkers. Tohoku J Exp Med 229: 173-185, 2013.

17. Lakshmi SV, Naushad SM, Reddy CA, Saumya K, Rao DS, Kotamraju S and Kutala VK: Oxidative stress in coronary artery disease: Epigenetic perspective. Mol Cell Biochem 374: 203-211, 2013.

18. Liu ZH, Chen LL, Deng XL, Song HJ, Liao YF, Zeng TS, Zheng J and Li HQ: Methylation status of CpG sites in the MCP-1 promoter is correlated to serum MCP-1 in Type 2 diabetes. J Endocrinol Invest 35: 585-589, 2012.

19. Jiang Y, Zhang H, Sun T, Wang J, Sun W, Gong H, Yang B, Shi Y and Wei J: The comprehensive effects of hyperlipidemia and hyperhomocy-steinemia on pathogenesis of atherosclerosis and DNA hypomethylation in ApoE -1- $^{--}$mice. Acta Biochim Biophys Sin (Shanghai) 44: 866-875, 2012.

20. Zulli A, Widdop RE, Hare DL, Buxton BF and Black MJ: High methionine and cholesterol diet abolishes endothelial relaxation. Arterioscler Thromb Vasc Biol 23: 1358-1363, 2003

21. Jiang Y, Sun T, Xiong J, Cao J, Li G and Wang S: Hyperhomo cysteinemia-mediated DNA hypomethylation and its potential epigenetic role in rats. Acta Biochim Biophys Sin (Shanghai) 39: 657-667, 2007.

22. Hagebeuk EE, Duran M, Abeling NG, Vyth A and Poll-The BT: $\mathrm{S}$-adenosylmethionine and S-adenosylhomocysteine in plasma and cerebrospinal fluid in Rett syndrome and the effect of folinic acid supplementation. J Inherit Metab Dis 36: 967-972, 2013.

23. Agardh HE, Gertow K, Salvado DM, Hermansson A, van Puijvelde GH, Hansson GK, N-Berne GP and Gabrielsen A: Fatty acid binding protein 4 in circulating leucocytes reflects atherosclerotic lesion progression in Apoe $\mathrm{e}^{(-/)}$mice. J Cell Mol Med 17: 303-310, 2013.

24. Maksimenko AV and Vavaev AV: Antioxidant enzymes as potential targets in cardioprotection and treatment of cardiovascular diseases. Enzyme antioxidants: The next stage of pharmacological counterwork to the oxidative stress. Heart Int 7: e3, 2012.

25. Linic IS, Sosa I, Kovacevic M, Ivancic A, Trobonjaca Z, Ledic D, Grubesic A, Dvornik S and Stifter S: Predicting carotid restenosis by comparison of plaque MCP-1 mRNA expression and serum levels. Med Hypotheses 80: 26-28, 2013.

26. Ikkruthi S, Rajappa M, Nandeesha H, Satheesh S, Sundar I, Ananthanarayanan $\mathrm{PH}$ and Harichandrakumar KT: Hyperhomocysteinemia and hyperlipoproteinemia (a) in obese south indian men: An indication for increased cardiovascular risk. Acta Physiol Hung 101: 13-20, 2014.

27. Ajith TA and Ranimenon: Homocysteine in ocular diseases. Clin Chim Acta 450: 316-321, 2015.

28. Wang Y, Chen S, Yao T, Li D, Wang Y, Li Y, Wu S and Cai J: Homocysteine as a risk factor for hypertension: A 2-year follow-up study. PLoS One 9: e108223, 2014

29. Zhang D, Wen X, Wu W, Xu E, Zhang Y and Cui W: Homocysteine-related hTERT DNA demethylation contributes to shortened leukocyte telomere length in atherosclerosis. Atherosclerosis 231: 173-179, 2013.

30. Griffiths HR, Aldred S, Dale C, Nakano E, Kitas GD, Grant MG, Nugent D, Taiwo FA, Li L and Powers HJ: Homocysteine from endothelial cells promotes LDL nitration and scavenger receptor uptake. Free Radic Biol Med 40: 488-500, 2006.

31. Hagebeuk EE, Duran M, Abeling NG, Vyth A and Poll-The BT: $\mathrm{S}$-adenosylmethionine and $\mathrm{S}$-adenosylhomocysteine in plasma and cerebrospinal fluid in Rett syndrome and the effect of folinic acid supplementation. J Inherit Metab Dis 36: 967-972, 2013.

32. Yideng J, Jianzhong Z, Ying H, Juan S, Jinge Z, Shenglan W, Xiaoqun $\mathrm{H}$ and Shuren $\mathrm{W}$ : Homocysteine-mediated expression of SAHH, DNMTs, MBD2, and DNA hypomethylation potential pathogenic mechanism in VSMCs. DNA Cell Biol 26: 603-611, 2007.

33. Yang XL, Tian J, Liang Y, Ma CJ, Yang AN, Wang J, Ma SC, Cheng Y, Hua X and Jiang YD: Homocysteine induces blood vessel global hypomethylation mediated by LOX-1. Genet Mol Res 13: 3787-3799, 2014.

34. Enneman AW, van der Velde N, de Jonge R, Heil SG, Stolk L, Hofman A, Rivadeneira F, Zillikens MC, Uitterlinden AG and van Meurs JB: The association between plasma homocysteine levels, methylation capacity and incident osteoporotic fractures. Bone 50: 1401-1405, 2012. 
35. Maegawa S, Hinkal G, Kim HS, Shen L, Zhang L, Zhang J, Zhang N, Liang S, Donehower LA and Issa JP: Widespread and tissue specific age-related DNA methylation changes in mice. Genome Res 20: 332-340, 2010.

36. Holm S, Ueland T, Dahl TB, Michelsen AE, Skjelland M, Russell D, Nymo SH, Krohg-Sørensen K, Clausen OP, Atar D, et al: Fatty acid binding protein 4 is associated with carotid atherosclerosis and outcome in patients with acute ischemic stroke. PLoS One 6: e28785, 2011.

37. Orekhov AN, Sobenin IA, Gavrilin MA, Gratchev A, Kotyashova SY, Nikiforov NG and Kzhyshkowska J: Macrophages in immunopathology of atherosclerosis: A target for diagnostics and therapy. Curr Pharm Des 21: 1172-1179, 2015.

38. Shepard CW and Steinberger J: Premature atherosclerotic cardiovascular disease in childhood cancer survivors. Prog Pediatr Cardiol 39: 59-66, 2015.

39. Cash HL, McGarvey ST, Houseman EA, Marsit CJ, Hawley NL, Lambert-Messerlian GM, Viali S, Tuitele J and Kelsey KT: Cardiovascular disease risk factors and DNA methylation at the LINE-1 repeat region in peripheral blood from Samoan Islanders Epigenetics 6: 1257-1264, 2011.

40. Connelly JJ, Cherepanova OA, Doss JF, Karaoli T, Lillard TS Markunas CA, Nelson S, Wang T, Ellis PD, Langford CF, et al: Epigenetic regulation of COL15A1 in smooth muscle cell replicative aging and atherosclerosis. Hum Mol Genet 22: 5107-5120, 2013.

41. Terra X, Quintero Y, Auguet T, Porras JA, Hernández M, Sabench F, Aguilar C, Luna AM, Del Castillo D and Richart C: FABP 4 is associated with inflammatory markers and metabolic syndrome in morbidly obese women. Eur J Endocrinol 164: 539-547, 2011

42. Lisanti S, Omar WA, Tomaszewski B, De Prins S, Jacobs G, Koppen G, Mathers JC and Langie SA: Comparison of methods for quantification of global DNA methylation in human cells and tissues. PLoS One 8: e79044, 2013. Wagner C and Koury MJ: S-Adenosylhomocysteine: A better indicator of vascular disease than homocysteine? Am J Clin Nutr 86: 1581-1595, 2007.

43. Girona J, Rosales R, Plana N, Saavedra P, Masana L and Vallvé JC: FABP4 induces vascular smooth muscle cell proliferation and migration through a MAPK-dependent pathway. PLoS One 8: e81914, 2013

44. Yang AN, Zhang HP, Sun Y, Yang XL, Wang N, Zhu G, Zhang H, $\mathrm{Xu} \mathrm{H}, \mathrm{Ma} \mathrm{SC}$, Zhang Y, et al: High-methionine diets accelerate atherosclerosis by HHcy-mediated FABP4 gene demethylation pathway via DNMT1 in ApoE(-/-) mice. FEBS Lett 589: 3998-4009, 2015.
45. Laukkanen MO, Kivelä A, Rissanen T, Rutanen J, Karkkainen MK, Leppanen O, Bräsen JH and Yla-Herttuala S: Adenovirus-mediated extracellular superoxide dismutase gene therapy reduces neointima formation in balloon-denuded rabbit aorta. Circulation 106: 1999-2003, 2002.

46. Giovannone R, Busetto GM, Antonini G, De Cobelli O, Ferro M, Tricarico S, Del Giudice F, Ragonesi G, Conti SL, Lucarelli G, et al: Hyperhomocysteinemia as an early predictor of erectile dysfunction: International Index of Erectile Function (IIEF) and penile doppler ultrasound correlation with plasma levels of homocysteine. Medicine (Baltimore) 94: e1556, 2015.

47. Kim SJ, Choe YH and Bang OY; Chaos-Biomarker Collaborators: Are stroke biomarkers seeing brain vessels in patients with ischemic stroke?: A C-reactive protein and homocysteine study. Stroke 42: 1464-1468, 2011

48. Cummings DM, King DE, Mainous AG and Geesey ME: Combining serum biomarkers: The association of C-reactive protein, insulin sensitivity, and homocysteine with cardiovascular disease history in the general US population. Eur J Cardiovasc Prev Rehabil 13: 180-185, 2006.

49. Liu C, Wang Q, Guo H, Xia M, Yuan Q, Hu Y, Zhu H, Hou M, Ma J, Tang Z and Ling W: Plasma S-adenosylhomocysteine is a better biomarker of atherosclerosis than homocysteine in apolipoprotein E-deficient mice fed high dietary methionine. J Nutr 138: 311-315, 2008.

50. Han XB, Zhang HP, Cao CJ, Wang YH, Tian J, Yang XL, Yang AN, Wang J, Jiang YD and Xu H: Aberrant DNA methylation of the PDGF gene in homocysteine-mediated VSMC proliferation and its underlying mechanism. Mol Med Rep 10: 947-954, 2014

51. Perng W, Villamor E, Shroff MR, Nettleton JA, Pilsner JR, Liu Y and Diez-Roux AV: Dietary intake, plasma homocysteine, and repetitive element DNA methylation in the Multi-Ethnic Study of Atherosclerosis (MESA). Nutr Metab Cardiovasc Dis 24: 614-622, 2014

52. Zhao J, Forsberg CW, Goldberg J, Smith NL and Vaccarino V: MAOA promoter methylation and susceptibility to carotid atherosclerosis: Role of familial factors in a monozygotic twin sample. BMC Med Genet 13: 100, 2012.

53. Wilson AS, Power BE and Molloy PL: DNA hypomethylation and human diseases. Biochim Biophys Acta 1775: 138-162, 2007. 